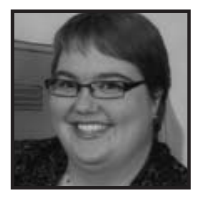

\title{
Learning to Lead: A New Teacher's Perspectives on Teacher Leadership
}

\author{
Kristie Bridges, Riverside School Board
}

\begin{abstract}
The question of teacher leadership is inextricably tied to teacher effectiveness. Leadership forms the foundation of classroom management and permeates all aspects of the curriculum. While many new teachers have visions of the kinds of leaders they wish to become, this vision is often complicated by the everyday realities of classroom life. Faced with increasingly difficult circumstances, it becomes infinitely more important for teachers to foster the trust and confidence required to make meaningful connections with their students. This article discusses the qualities of effective leaders and the impact of effective leadership on students. It also considers some of the challenges that arise when pursuing one's vision of leadership.
\end{abstract}

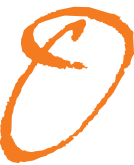

ne of the most important challenges facing new teachers is that of teacher leadership. Graduating from teacher preparation programs and embarking on a new career is an overwhelming experience. Setting foot in a classroom for the first time is intimidating and being responsible for the education of a group of young people is daunting. Despite the preparation offered by teacher programs, there is nothing that can compare with being in the classroom. When preparing for a new class, the notion of teacher leadership is often overlooked, though it should not be. I began teaching last year. At the beginning of the year, I started planning my curriculum, choosing themes and planning lessons. I thought about the strategies I would use to manage my students' behaviour. Yet, I did not really consider myself to be a leader. Yes, I was in charge of my class, but a leader? Leader somehow seemed too strong a word. It suggested something much more than what I was. But I was a leader. I am a leader. 
It is my view that all teachers are leaders, whether they label themselves as such or not. A teacher's job is to construct knowledge with her students, and empower them to become contributing citizens. While presenting information and evaluating students' learning, teachers assume a leadership role. This does not mean that teachers are simply authority figures who "have all the answers." Rather, it is a teacher's job to bring her students to an understanding of the subject matter. In so doing, teachers are leaders. However, teacher leadership extends beyond the curriculum. In many ways, school is a child's home away from home and teachers are responsible for students' well-being while in their care. Teachers need to show children how to interact with one another, how to solve conflicts, how to overcome adversity. Ideally, teachers show students how to become responsible people.

In order to communicate my ideas about teacher leadership, I must consider what I learned in my teacher preparation program. I inevitably draw on my own experiences in the classroom. My experience may be limited, but I have learned a great deal in a short period of time. I am not the same teacher I was a year ago and I hope to be a different teacher a year from now. My view of teacher leadership is in constant evolution and as I think about both what I have accomplished and the difficulties I have faced, I believe that I have come to a deeper understanding of my role as a teacher and as a leader.

Afternoons in kindergarten are always noisy. Students engage in their favourite free play activities, while I work with students on unfinished work or oneon-one evaluations. One afternoon, I heard one student shout at another: "Sit down! Hey! Listen!" I was immediately compelled to intervene. After all, kindergarten is about learning how to be friends and bossing others around is a behaviour I aim to discourage. Then it occurred to me that these commands were all part of the game. The students were playing teacher. That night, as I drove home, I caught myself replaying the afternoon's events in my mind. I heard the students' voices as they pretended to be the teacher. I am the only teacher they have ever had; I thought they must be doing their very best impression of me. And then it occurred to me: is that really the kind of teacher I am?

So much about being a teacher is not about reading and writing and mathematics. So much has nothing to do with science projects or history facts or physical education. Curriculum is important, but it is only one part of teaching and learning. The other part is about leadership. It's about showing children how to be responsible. It is about attitude and respect. Curriculum and leadership are inextricably linked. No teacher can aspire to be a good teacher without considering both. 
New teachers receive specialized instruction about how to teach subject matter in teacher preparation programs. Psychology classes are compulsory, all with the goal of helping education students gain an understanding of child development. The various theories and philosophical foundations of education are analyzed in depth. There is no class about leadership, yet it is a fundamental aspect of teaching. Why? It is certainly no fault of university administrators and program directors. The simple truth, perhaps, is that much about leadership cannot be taught. Quinn, Haggard and Ford (2006) suggest that perhaps new teachers would be more likely to emerge as leaders if they were explicitly taught leadership strategies through a defined course of study. Their proposal outlines ways to foster leadership skills within the classroom and with teacher peers. Also, it includes leadership skills for coaching and mentoring future teachers and for developing relationships within the profession. What is most pertinent to this discussion is Quinn et al.'s (2006) acknowledgment that fieldwork done by preservice teachers provides "limited, and often contrived, opportunities to practice newly acquired skills" (p. 57). They contend that students in teacher preparation programs need to be taught leadership skills in order to become effective teachers. Leadership, they maintain, differentiates "adequate performance [from] excellent performance" (Quinn, et al., 2006, p. 60). While these authors do propose a framework for the teaching of such leadership skills in teacher preparation programs, the fact remains that many university programs today offer such instruction only in passing, thus signifying that many new teachers are faced with the considerable challenge of learning how to be a leader while in the classroom.

Teachers lead how they live; no two teachers envision leadership in quite the same way. One's vision of leadership develops over time, and it is my view that as new teachers graduate from teacher preparation programs, most have a very clear picture of the kind of leader they want to be. Deciding on the kind of leader one wants to be is fairly easy. Becoming this leader is not quite as simple.

My vision of leadership is based on respect, strength and patience. Leadership is about making connections. No teacher can hope to build a rapport with her students without treating them with respect. It may be cliché to cite the old adage, "treat others as you would like to be treated," but in my experience, it has certainly proven to be true. Children need to feel like they matter, that they are important to the teacher and that their best interests are being considered. San Antonio and Salzfass's (2007) study of bullying among middle school students indicated that students "made it clear that they value fairness, respectful communication, and adults who make them feel physically and emotionally safe and cared for" (p. 38). When students feel safe, they are ready to learn. For teachers to be able to work effectively, their 
students need to be receptive to learning. In order to achieve this, good leaders need not give children everything they want or accept all of their requests. Nor does it mean that negative consequences are never handed out. A good leader helps students to recognize that sometimes consequences are necessary and deserved. A leader's goal must also be to help students realize that their individual behaviours have an impact on the class as a whole. A good leader also knows that imposing consequences does not mean blindly imposing authority. When teachers are respected, when they have invested time in connecting with the students, students are more readily able to be a positive presence in the classroom community.

To be a good leader, teachers must be equally patient with their students, as with themselves. As anyone dealing with young people can attest, patience is a key element of interactions with children. Children sometimes make mistakes and they sometimes resist authority. Effective leaders give children the chance to make those mistakes and are cognizant of the fact that children's worth is not determined by a single action. It is also important to be mindful that it takes time to build the connections between teachers and students. These connections are the key to positive leadership.

I came upon my first teaching contract somewhat by accident; I did not expect to spend the year teaching sixth grade in French immersion, nor did the students expect to have me as a teacher all year. The first few months were difficult for all of us. It took both the students and me some time to get to know one another and to learn to trust each other. In the beginning, the students looked at me as little more than a temporary stand-in. They disputed many of the things that I said and were reluctant to follow rules without challenging them. At first, there is no doubt that I was not entirely the kind of leader I wanted to be.I didn't know how to approach the students, and was somewhat intimidated by them. I had never envisioned that I would teach sixth grade and, true to my expectations, it was not always easy. I tried to be authoritarian, doling out severe consequences for even the smallest transgression. This did not work. I tried to be far too accommodating, which was perhaps even less successful, because I ended up losing control of what was going on in my classroom. I realized that I needed to be somewhere in between. Slowly, but surely, we were able to navigate through the rough patches and come to a point where there was mutual respect and a sense of responsibility for what went on in the classroom. I needed to convey to the students that we were going to be together for the year and that we were all accountable for our successes and failures as a class. I needed to show them that I was their leader and that we, together, were going to accomplish great things, but that we needed to trust each other first. This trust meant that they needed to respect my authority and that I would need to give them a voice in the classroom. 
In the beginning, I implemented a system of rewards and consequences. I explicitly outlined which behaviours I would reward and those that merited consequences. Listening, participating and staying on task got the students closer to an agreed-upon reward activity of their choice, while disruptions and incomplete work often led to notes home or recesses indoors. The students realized that there was a certain standard of behaviour in the classroom and that I would not tolerate behaviours that interfered with my teaching or, worse, students' learning. Because unacceptable behaviours were clearly outlined, students accepted consequences more readily. As the year went on, it seemed that I did not have to resort to rewards and consequences as frequently. The acceptable behaviour became second nature to the students.

I also spent a great deal of time outside of class simply talking to my students about their likes and dislikes and what they did in their spare time. I paid attention to their interests. They came to tell me things about themselves spontaneously and I shared with them certain aspects of my own life. For many teachers, sharing personal information with students is a breach of professionalism, but I think there is a way to share likes and dislikes without divulging information that blurs that line between teacher and student. By talking to students, I became a real person to them. When I listened to them, they realized they could trust me. This helped to strengthen our connection, but it took a great deal of time and patience for our relationship to blossom.

Finally, leadership requires strength of character. It is a struggle to consistently be a constructive leader. It takes strength for teachers to analyze the kind of leaders they are and make the necessary changes. It is not easy to be a leader every day. The fact is, however, that teachers are leaders no matter what they do. The difficult thing is to become a positive leader. Whenever I think of educators as leaders, I inevitably think of Miss Trunchbull, the tyrannical principal from Roald Dahl's (2007) fabulous Matilda. Miss Trunchbull's memorable lines always come to mind: "You were wrong! [...] In fact, you strike me as the sort of poisonous little pockmark that will always be wrong! You sit wrong! You look wrong! You speak wrong! You are wrong all around!" (Dahl, 2007, p. 152). In fact, when I consider myself as a leader, I take an informal inventory of all of my Miss Trunchbull's moments and make it a point to minimize these in the future. One of my greatest faults as a teacher is that I am easily flustered when my attempts to deal with students who are inattentive or disruptive are unsuccessful. On occasion, I let my frustration show and I lose my temper. At times, I have raised my voice simply to assert authority and I have doled out consequences impulsively. Having realized that this is one of my weaknesses as a teacher, I know that I 
must continually assess situations to make sure that the consequences are fair. Was I too harsh? Too lenient? Was I patient enough? Too tolerant? Asking myself these questions allows me to improve. Ackerman and Mackenzie's (2006) discussion of teacher leaders discusses how even veteran teachers who have relatively firm beliefs about the nature of teaching and have fairly stable instructional practices, must continually "gauge the extent to which their practices align with their philosophies" (p. 67). Effective teachers change over time, as they learn more about students, teaching strategies and classroom management approaches. The key is to consider one's instructional practices and how these fit with one's vision of an effective teacher.

Why is leadership so important? Leadership is the foundation of classroom management. While so many classroom management approaches exist, along with countless systems of rewards and consequences, these are most effective when the teacher implementing them is a good leader. Rewards and consequences are more meaningful when they come from someone the students are attached to, someone the students believe in. In kindergarten, I can tell that my relationship with the students is directly related to the kinds of interactions I have with them. When one child hits another, for example, I am sure to take that child aside and discuss what happened. I always ask the students how they feel and how they imagine the other student feels, and I am also sure to tell them that this kind of behaviour worries me because it is unsafe. I often tell them it makes me unhappy to see my students treating each other so poorly. When I share my feelings with the students, I can tell that they understand the severity of their actions. Our conversations are meaningful, thanks to the relationship that we have built over the course of the year.

It is a relatively simple thing to describe a vision of leadership. When I think of a teacher as a good leader, I think of someone students listen to because they respect her. I envision a person who is dynamic and entertaining, but also firm in her classroom management. I think of someone who is clear in her expectations and who engages her students. Carrying out this vision, however, is infinitely more complicated than simply describing it. In an ideal world, the enthusiastic teacher would effortlessly act the way she believed a leader should act and eager students would respond favourably. However, there are so many external factors that come into play in the classroom. Classroom life does not take place in a vacuum. Teachers must constantly adjust their ways of doing things to suit the needs of their students. The reality in today's classrooms is that many students are disinterested and unmotivated and this results in behaviour that greatly influences the classroom dynamic. Some students are unhappy at home and are preoccupied with events occurring in their family lives. Others have learning challenges that have spawned a disinterest in school because it 
has become too difficult. There are many more reasons for disruptive behaviours and, ultimately, they are irrelevant to this discussion. Regardless of the reasons behind them, the fact remains that problematic behaviours are an unavoidable part of classroom life. It is by living in the classroom that teachers learn how to approach the so-called difficult students and address behaviour problems. Meuwissen (2005, p. 256.) discusses the dichotomy between ideal classroom and "today's classrooms" in the context of preservice teachers' internship experiences. He describes preservice teachers' change in attitude near the beginning and end of a methods course. He notes a change from optimism and innovation to cynicism and defeat as preservice teachers spent more time in the classroom. He indicates that there is thus a need to adapt teacher preparation programs to address the apparent discrepancy between preservice teachers' expectations of classroom life and the realities they witness during their fieldwork (p. 257). I suggest that Meuwissen's observations apply beyond the context of teacher preparation programs. Even with a year of teaching experience, I continually need to find ways to adapt my vision of an ideal classroom to work in my everyday context.

In my dealings with challenging students, I have occasionally resorted to Miss Trunchbull antics. I have lost my temper and have used my authority in ways that were not constructive. There have been moments when I have gotten caught up in my emotions and have not dealt with my frustrations effectively. On those days, I have tried to look for what went wrong and come up with a plan of action for the future. I think that new teachers inch their way closer to their visions of leadership every day; the important thing is that they slowly approximate their definition of a leader.

It is important to discuss leadership explicitly with students. No matter how young or old, students are partially responsible for how the classroom operates. If the teacher is a proficient leader, then she can point students in the right direction, but the students are still responsible for following the teacher's lead. I have had numerous discussions with my kindergarteners and my sixth-graders about how we are operating as a class and why it is important to adjust certain behaviours in order to accomplish our goals. Talking out loud about the classroom community and sharing ideas with students are part of being a good leader. It gives students some control and voice, and allows them to understand the teacher's role as a leader.

Am I the kind of leader I want to be? Not yet, but I'm getting there. I am learning how to be a good leader, through my successes and, perhaps more importantly, through my failures. I have known all along that becoming the kind of leader I want to be would not be easy. In fact, teacher leadership is very complex and not easy 
for anyone to master. The realities of classroom life call for persistence and creativity on the teacher's part, in order to develop the kind of relationship with students that will permit effective classroom management while creating an environment that is conducive to learning. I noticed my kindergarteners imitating me again more recently. They were playing with puppets, repeating the exact conflict resolution scenario I had done with them that morning. "You can solve your own problems," they told each other, "Here's a solution: let's share." Maybe imitating me is not such a bad thing after all.

\section{References}

Ackerman, R. \& Mackenzie, S. V. (2006). Uncovering teacher leadership. Educational Leadership, 63(8), 66-70.

Dahl, R. (2007). Matilda. New York: Puffin. Original work published 1988.

Meuwissen, K. W. (2005). Maybe someday the twain shall meet: Exploring disconnections between methods instruction and "life in the classroom". Social Studies, 96(6), 253-258.
Quinn, C. L., Haggard, C. S. \& Ford, B. A. (2006). Preparing new teachers for leadership roles: a model in four phases. School Leadership and Management, 26(1), 55-68.

San Antonio, D.M. \& Salzfass, E. A. (2007). How we treat one another in school. Educational Leadership, 64(8), 32-38.

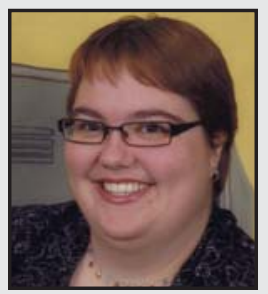

Kristie Bridges graduated from Concordia University with a Bachelor of Arts with Specialization in Early Childhood and Elementary Education in 2006. She has been teaching in the Riverside School Board near Montreal for two years, in kindergarten and in cycle three, both in English and in French immersion. Switching between kindergarten and cycle three has been both challenging and enriching and has provided a unique perspective on which to build in future years. 